\title{
Genetic structure and diversity in the Dioscorea cayenensis/D. rotundata complex revealed by morphological and isozyme markers
}

\author{
E.A. Bressan ${ }^{1}$, T. Briner Neto ${ }^{1}$, M.I. Zucchi ${ }^{2}$, R.J. Rabello ${ }^{1}$ and E.A. Veasey ${ }^{1}$ \\ 'Departamento de Genética, Escola Superior de Agricultura "Luiz de Queiroz", \\ Universidade de São Paulo, Piracicaba, SP, Brasil \\ ${ }^{2}$ Agência Paulista de Tecnologia dos Agronegócios, Pólo Apta Centro Sul, \\ Piracicaba, SP, Brasil
}

Corresponding author: E.A. Veasey

E-mail: eaveasey@usp.br

Genet. Mol. Res. 13 (1): 425-437 (2014)

Received August 12, 2013

Accepted October 18, 2013

Published January 21, 2014

DOI http://dx.doi.org/10.4238/2014.January.21.10

\begin{abstract}
Of the 600 known yam species, only 10 are utilized as food, and the Dioscorea cayenensis/D. rotundata species complex is among the most cultivated. In Brazil, these species are commercially cultivated in the northeast region and are cultivated in the south and southeast regions as subsistence crops by traditional agriculturists. This study aimed to evaluate the genetic diversity of 21 local varieties of $D$. cayenensis and $2 D$. rotundata accessions using 7 isozymic loci and 24 morphological markers, and to investigate the diversity distribution in different levels of organization, such as swidden fields and communities of Vale do Ribeira. Cluster analyses for both the isozymic and morphological data separated the $2 \mathrm{D}$. rotundata accessions from the $D$. cayenensis accessions from Vale do Ribeira. The analysis with morphological characteristics showed the presence of 2 subgroups (Iguape and Cananéia) within group I, which included all of the local
\end{abstract}


varieties from Vale do Ribeira; this result may indicate the influence of the cultural units on the morphological variation. Molecular analysis of variance indicated that most of the isozymic variability was concentrated among swiddens within communities (42.5\%) and within communities (40.3\%). Most of the morphological variability was also concentrated among swidden fields within communities (44.8\%). The correlation between geographic and genetic distances indicated that neither morphological $(\mathrm{r}=0.17)$ nor isozymic diversity $(\mathrm{r}=-0.15)$ is structured in space. Thus, the traditional agriculturists of Vale do Ribeira maintain and manage a great diversity of $D$. cayenensis varieties in their communities.

Key words: Traditional agriculture; Genetic variability; Morphological traits; Molecular analysis of variance

\section{INTRODUCTION}

Yams (Dioscorea spp) are found in tropical regions, and different edible species were domesticated independently in America, Africa, and South and Southeast Asia (Lebot, 2009). Worldwide, yam production amounted to 52 million tons, of which Africa produced $96 \%$. Most of the world production comes from West Africa, with Nigeria alone producing $71 \%$ (IITA, 2009; FAO, 2011). The other producing areas are located in Asia and America. Brazil is responsible for $0.5 \%$ of world production, which was 49.2 million tons in 2009 (FAO, 2011). Of the 600 known species of yams, 10 are used as food. Dioscorea cayenensis Lam. and D. rotundata Poir. are among the most cultivated species (Lebot, 2009).

The main yam-producing states in Brazil are located in the Northeast, where the predominant cultivated species belongs to the D. cayenensis/D. rotundata complex (Veasey et al., 2010). In the southeast region of Brazil, traditional farmers of Vale do Ribeira cultivate this species complex in plantations in a slash and burn system (Bressan et al., 2005). These species are grown in abandoned fields, or fallow, where the vegetation of the Atlantic Forest is in regeneration. Thus, the traditional farmer favors the amplification of species diversity through mechanisms such as the spatial arrangement of plants, introduction of new varieties, and farming system (slash and burn) (Martins and Oliveira, 2009).

Previous research was carried out using morphological and isozyme analysis to study the genetic diversity of local varieties of $D$. alata $\mathrm{L}$. that were cultivated by traditional farmers in Vale do Ribeira (Bressan et al., 2011). In Africa, the species complex D. cayenensis/D. rotundata was also studied using isozyme and morphological markers (Hamon and Toure, 1990; Zoundjihekpon et al., 1994; Dansi et al., 1999, 2000a; Mignouna et al., 2002). Accessions of these species were also evaluated with random amplified polymorphic DNA, amplified fragment length polymorphism (Asemota et al., 1996; Dansi et al., 2000b; Mignouna et al., 2003), and simple sequence repeat markers (Scarcelli et al., 2005; Obidiegwu et al., 2009a). Mignouna et al. (2005) concluded that cultivars that were classified as D. cayenensis should be considered as a taxon that was separate from $D$. rotundata.

The aim of this study was to estimate the genetic diversity of $D$. cayenensis local varieties that were cultivated by traditional farmers of Vale do Ribeira. This was accomplished 
by assessing genetic (isozymes) and morphological characteristics and comparing them with those of $D$. rotundata accessions. This study also aimed to study spatial correlations, comparing geographic and genetic (isozymes and morphology) distances and the correlation between the markers.

\section{MATERIAL AND METHODS}

We evaluated $21 D$. cayenensis local varieties that were collected in the communities practicing traditional farming in Vale do Ribeira, São Paulo, in the municipalities of Cananéia $\left(25^{\circ} 00^{\prime} \mathrm{S} ; 47^{\circ} 55^{\prime} \mathrm{W}\right)$, Eldorado Paulista $\left(24^{\circ} 36^{\prime} \mathrm{S} ; 48^{\circ} 22^{\prime} \mathrm{W}\right)$, Iguape $\left(24^{\circ} 42^{\prime} \mathrm{S} ; 4^{\circ} 33^{\prime} \mathrm{W}\right)$, Ilha Comprida $\left(24^{\circ} 53^{\prime} \mathrm{S} ; 47^{\circ} 40^{\prime} \mathrm{W}\right)$, and Iporanga $\left(24^{\circ} 34^{\prime} \mathrm{S}\right.$; $\left.48^{\circ} 24^{\prime} \mathrm{W}\right)$ (Table 1, Figure 1$)$. In addition to the local varieties of Vale do Ribeira, 2 accessions that were identified as D. rotundata were also evaluated; 1 originated from the germplasm collection of Embrapa Mandioca e Fruticultura Tropical, located in the municipality of Cruz das Almas $\left(12^{\circ} 40^{\prime} \mathrm{S} ; 39^{\circ} 06^{\prime} \mathrm{W}\right)$, State of Bahia, and the other, called "cará do norte" (yam from the North), was obtained at a supermarket in the city of Piracicaba, São Paulo $\left(22^{\circ} 42^{\prime} \mathrm{S} ; 47^{\circ} 38^{\prime} \mathrm{W}\right)$. These 2 accessions were used in this study in order to compare the 2 species because they are part of a controversial issue concerning their taxonomic identification.

\begin{tabular}{|c|c|c|c|c|c|c|}
\hline \multirow{2}{*}{$\frac{\text { No. }}{1}$} & \multirow{2}{*}{$\begin{array}{l}\text { Municipality } \\
\text { Iguape }\end{array}$} & \multirow{2}{*}{$\begin{array}{l}\text { Community } \\
\text { Icapara }\end{array}$} & \multirow{2}{*}{$\frac{\text { Household }}{1}$} & \multirow{2}{*}{$\begin{array}{l}\text { Folk name } \\
\text { Cará de espinho }\end{array}$} & \multicolumn{2}{|c|}{ Geographical coordinates } \\
\hline & & & & & $24^{\circ} 40^{\prime} \mathrm{S}$ & $47^{\circ} 27^{\prime} \mathrm{W}$ \\
\hline 2 & Iguape & Praia do Leste & 2 & Cará de espinho & $24^{\circ} 41^{\prime} \mathrm{S}$ & $47^{\circ} 27^{\prime} \mathrm{W}$ \\
\hline 3 & Iguape & Vila Nova & 3 & Cará de espinho & $24^{\circ} 42^{\prime} \mathrm{S}$ & $47^{\circ} 40^{\prime} \mathrm{W}$ \\
\hline 4 & Iguape & Momuna & 4 & Cará de espinho & $24^{\circ} 42^{\prime} \mathrm{S}$ & $47^{\circ} 40^{\prime} \mathrm{W}$ \\
\hline 5 & Iguape & Momuna & 4 & Cará de espinho & $24^{\circ} 42^{\prime} \mathrm{S}$ & $47^{\circ} 41^{\prime} \mathrm{W}$ \\
\hline 6 & Iguape & Momuna & 5 & Cará de espinho & $24^{\circ} 36^{\prime} \mathrm{S}$ & $47^{\circ} 35^{\prime} \mathrm{W}$ \\
\hline 7 & Iguape & Momuna & 6 & Cará de espinho & $24^{\circ} 42^{\prime} \mathrm{S}$ & $47^{\circ} 33^{\prime} \mathrm{W}$ \\
\hline 8 & Iguape & Peropava & 7 & Cará de espinho & $24^{\circ} 42^{\prime} \mathrm{S}$ & $47^{\circ} 33^{\prime} \mathrm{W}$ \\
\hline 9 & Cananéia & S.P. Bagre & 8 & Cará de espinho & $24^{\circ} 57^{\prime} \mathrm{S}$ & $47^{\circ} 53^{\prime} \mathrm{W}$ \\
\hline 10 & Cananéia & S.P. Bagre & 8 & Cará d'angola & $24^{\circ} 57^{\prime} \mathrm{S}$ & $47^{\circ} 53^{\prime} \mathrm{W}$ \\
\hline 11 & Cananéia & Aroeira & 9 & Cará de espinho & $24^{\circ} 52^{\prime} \mathrm{S}$ & $47^{\circ} 52^{\prime} \mathrm{W}$ \\
\hline 12 & Cananéia & Rio Branco & 10 & Cará guaçu & $24^{\circ} 54^{\prime} \mathrm{S}$ & $48^{\circ} 00^{\prime} \mathrm{W}$ \\
\hline 13 & Cananéia & Ex-Colônia & 11 & Cará de espinho & $24^{\circ} 52^{\prime} \mathrm{S}$ & $48^{\circ} 00^{\prime} \mathrm{W}$ \\
\hline 14 & Cananéia & Palmeiras & 12 & Cará de espinho & $24^{\circ} 54^{\prime} \mathrm{S}$ & $48^{\circ} 01^{\prime} \mathrm{W}$ \\
\hline 15 & Cananéia & Santa Maria & 13 & Cará guaçu & $25^{\circ} 04^{\prime} \mathrm{S}$ & $48^{\circ} 08^{\prime} \mathrm{W}$ \\
\hline 16 & Ilha Comprida & Pedrinhas & 14 & Cará de espinho & $24^{\circ} 53^{\prime} \mathrm{S}$ & $47^{\circ} 40^{\prime} \mathrm{W}$ \\
\hline 17 & Ilha Comprida & Pedrinhas & 14 & Cará de espinho & $24^{\circ} 53^{\prime} \mathrm{S}$ & $47^{\circ} 40^{\prime} \mathrm{W}$ \\
\hline 18 & Ilha Comprida & Pedrinhas & 14 & Cará de espinho & $24^{\circ} 53^{\prime} \mathrm{S}$ & $47^{\circ} 40^{\prime} \mathrm{W}$ \\
\hline 19 & Iporanga & Nhunguara & 15 & Cará de espinho & $24^{\circ} 34^{\prime} \mathrm{S}$ & $48^{\circ} 24^{\prime} \mathrm{W}$ \\
\hline 20 & Eldorado Paulista & Sapatu & 16 & Cará de espinho & $24^{\circ} 36^{\prime} \mathrm{S}$ & $48^{\circ} 22^{\prime} \mathrm{W}$ \\
\hline 21 & Eldorado Paulista & Sapatu & 17 & Cará de espinho & $24^{\circ} 36^{\prime} \mathrm{S}$ & $48^{\circ} 22^{\prime} \mathrm{W}$ \\
\hline 22 & Cruz das Amas (EMBRAPA) & $* *$ & - & - & $12^{\circ} 40^{\prime} \mathrm{S}$ & $39^{\circ} 06^{\prime} \mathrm{W}$ \\
\hline 23 & Piracicaba & $* *$ & - & Cará do norte & $22^{\circ} 42^{\prime} \mathrm{S}$ & $47^{\circ} 38^{\prime} \mathrm{W}$ \\
\hline
\end{tabular}

**Dioscorea rotundata accessions.

From each farm that was visited in Vale do Ribeira, a yam variety represented by a tuber was collected except for households 4, 8, and 14 in the communities of Momuna (Iguape), São Paulo Bagre (Cananéia), and Pedrinhas (Ilha Comprida), respectively, where 2 or 3 tubers were collected that were identified as different varieties by the farmers (Table 1). The average number of local varieties per farm, therefore, was 1.2. These materials were first planted in 
pots in a greenhouse, and after 2 months, the seedlings were transplanted to an experimental field in ridges in Piracicaba, São Paulo. The experiment was installed in a soil type called Typic Haplustox, in a climate that was classified by the International Köeppen as Cwa. The spacing between rows and between plants was $1.50 \mathrm{~m}$, and bamboo stakes were used to guide the growth of plants.

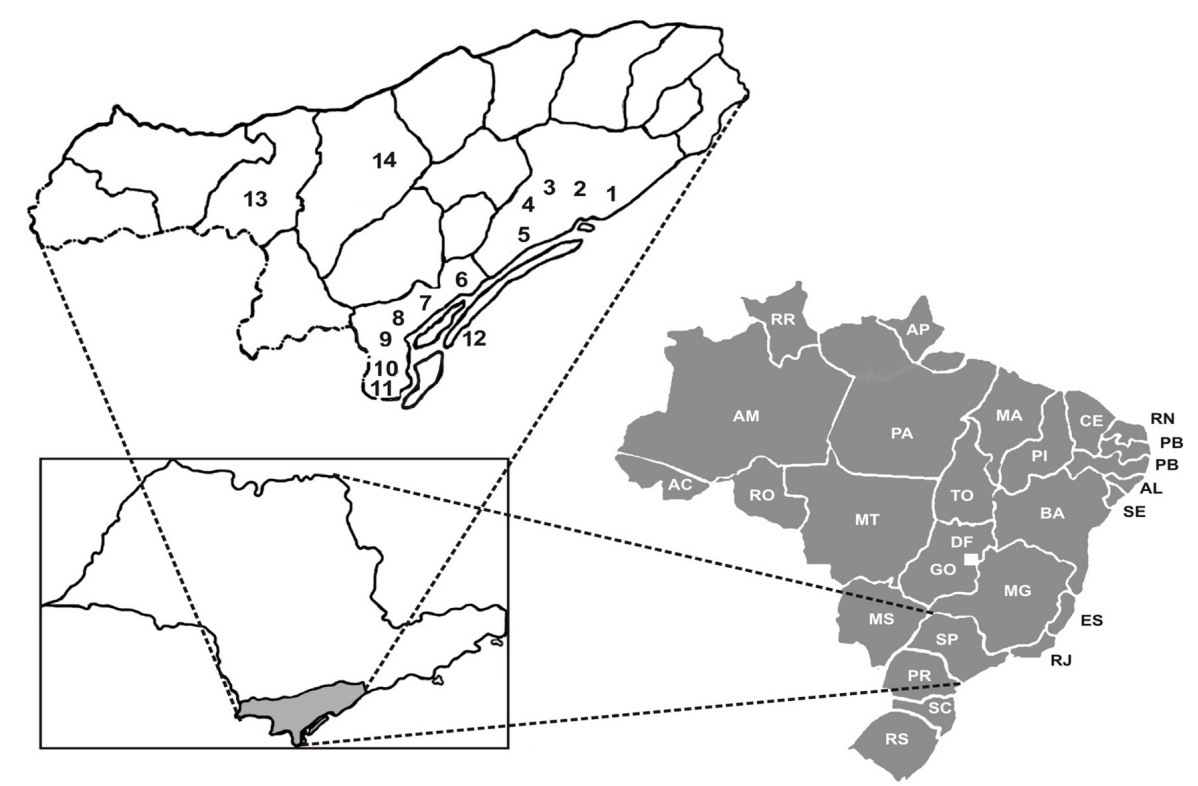

Figure 1. Map of the studied area in Vale do Ribeira, São Paulo, Brazil, showing the communities visited in the municipalities of Iguape (1 - Icapara, 2 - Praia do Leste, 3 - Vila Nova, 4 - Momuna, 5 - Peropava), Cananéia (6 - São Paulo Bagre, 7 - Aroeira, 8 - Rio Branco, 9 - Ex-Colônia, 10 - Palmeiras, 11 - Santa Maria), Ilha Comprida (12 - Pedrinhas), Iporanga (13 - Nhumguara) and Eldorado (14 - Sapatu).

\section{Morphological analysis}

The morphological evaluations were conducted in individual plants of each variety, with no replication, in the experimental field. For this analysis, we used the morphological traits that were recommended by the International Plant Genetic Resources Institute (IPGRI) and International Institute of Tropical Agriculture (IITA), Ibadan, Nigeria (IPGRI/ IITA, 1997). We also used the Dioscorea spp species identification key (IPGRI/IITA, 1997) to separate accessions from $D$. cayenensis and D. rotundata, also consulting Martin and Rhodes (1978) for this purpose.

The 21 local varieties that were grown by farmers in Vale do Ribeira and the $2 D$. rotundata accessions were evaluated using 19 descriptors that were associated to stem (6), leaf (4), tuber characteristics (8), and flowering (1) (Table 2). The morphological evaluations were performed in 2 stages: the first assessment was carried out 6 months after transplanting the accessions in the field because there was sufficient availability of tissues (young leaves, adult leaves, and stems), and the second was during harvest when the tubers were already formed. 


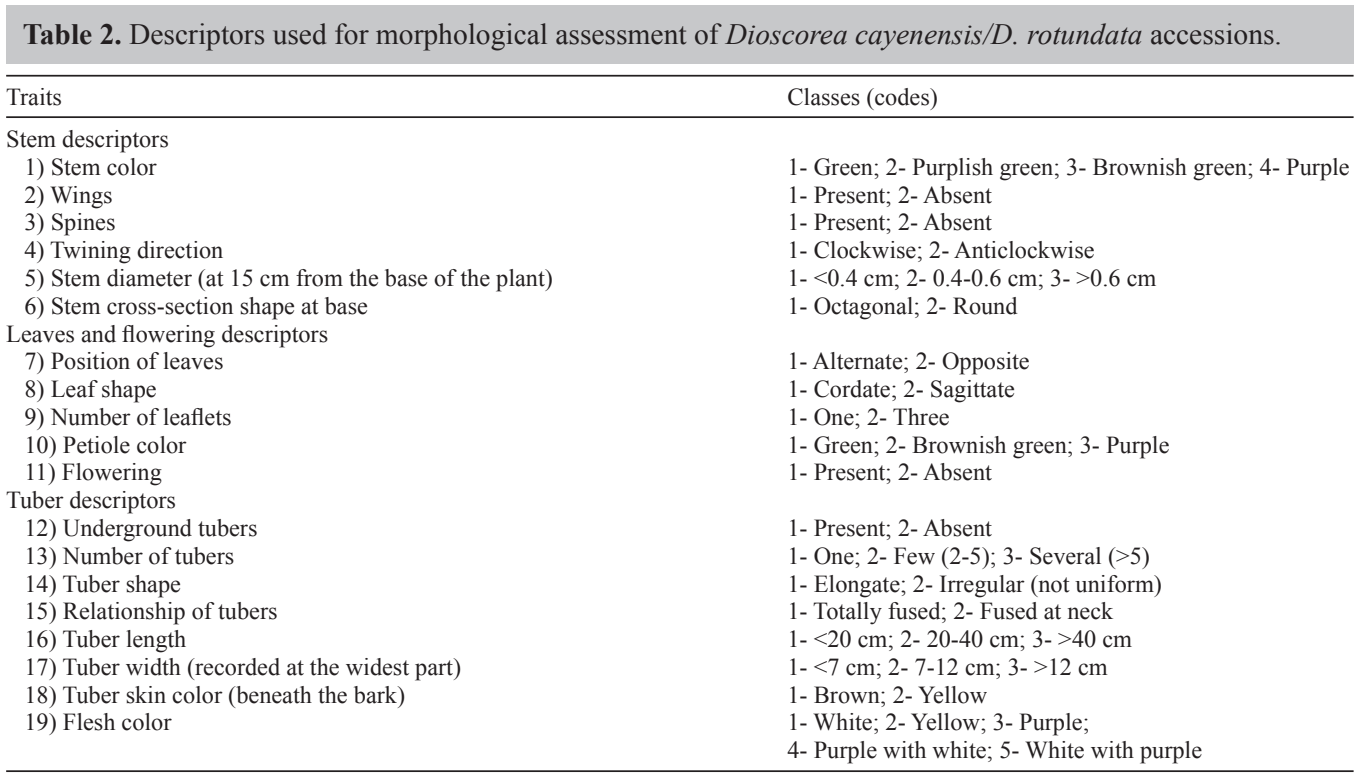

The observations were based on the phenotypic mean of 10 measurements for the quantitative traits in each plant. The qualitative data were assessed using grades. Flowering and fruiting were also observed because some traditional farmers reported the presence of small white flowers in the cará de espinho (spine yams) or cará d'Angola, which are popular names that are attributed to $D$. cayenensis in Vale do Ribeira.

\section{Isozymatic analysis}

The enzymes were extracted from recently expanded leaves $(200 \mathrm{mg})$ from adult plants (6-8 months), and the procedures were performed according to Bressan et al. (2011). Six systems were used with polyacrylamide gels: glucose-6-phosphate isomerase (GPI; E.C. 5.3.1.9), aspartate aminotransferase (AAT; E.C. 2.6.1.1), phosphoglucomutase (PGM; E.C. 2.7.5.1), shikimate dehydrogenase (SKD; E.C. 1.1.1.25), glucose-6-phosphate dehydrogenase $\left(\mathrm{G}_{6} \mathrm{PDH}\right.$; E.C. 1.1.1.49), and superoxide dismutase (SOD; E.C. 1.15.1.1). The malate dehydrogenase system (MDH; E.C. 1.1.1.37) was evaluated using a starch gel. After electrophoresis, the enzymes were revealed according to Alfenas et al. (1991), and the gels were interpreted and photographed immediately afterward.

\section{Statistical analyses}

Because of the polyploid nature of $D$. cayenensis/D. rotundata (Obidiegwu et al., 2009 b), data were genotyped as binary data (presence $=1$ and absence $=0$ ), generating a binary matrix. The morphological data were also analyzed by transforming each character state into a code within each descriptor, and these codes were subsequently transformed into binary data. For the isozymatic analyses, the number of bands per isozyme system, the total number of bands, and the percentage of polymorphic bands were also registered. 
Cluster analyses were performed with Jaccard's coefficient and the unweighted pair group method with an arithmetic mean clustering method using the NTSYSpc software version 2.0 (Rohlf, 1992). The group stability in the dendrograms was based on estimates of genetic dissimilarities by resampling with 1000 bootstraps using the BOOD version 2.0 program (Coelho, 2001).

Binary matrices of allozyme and morphological data were used for analysis of molecular variance (AMOVA) for a better understanding of the distribution of diversity according to the hierarchical levels (households and communities). AMOVA was used only for the materials that were collected in the fields of traditional farmers in Vale do Ribeira. For this purpose, we used the squared distances as described by Excoffier et al. (1992) with the program Arlequin (Excoffier et al., 2006).

For analysis of spatial variation, we correlated genetic diversity (isozymatic and morphological genetic distances) with spatial structure (geographic distances) to understand the evolutionary dynamics of this crop within traditional agricultural systems in Vale do Ribeira. The Pearson correlation coefficient ( $\mathrm{r}$ ) was used through the matrix of genetic distances that were calculated by the Jaccard similarity index and geographical distance between the collection sites. Geographical distances were estimated from the original coordinates of the home gardens and swidden fields using the TrackMaker version 12.3 software (Ferreira Junior, 2004). The Pearson correlation coefficient (r) was also used to verify the association between the isozymatic and morphological diversity. The significance levels of correlations were checked by the Mantel test $(Z)$ using 1000 random permutations (Mantel, 1967). The similarity matrices and the Mantel test were obtained using the NTSYSpc version 2.0 software (Rohlf, 1992).

\section{RESULTS AND DISCUSSION}

\section{Isozymatic analysis}

A total of 65 bands were revealed for all systems, with SOD presenting the highest number (13), followed by SKD with 12, AAT, G PDH, and GPI with 9, MDH with 7, and PGM with 6. All bands (100\%) were polymorphic. The combination of the different bands allowed the discrimination of 17 landraces from the 21 that were analyzed, in addition to the 2 D. rotundata accessions. This polymorphism is indicative of a high genetic variability that is maintained in the households of traditional farmers in Vale do Ribeira, São Paulo. To our knowledge, this is the first report on the genetic diversity within the $D$. cayenensis/D. rotundata species complex in Brazil. Dansi et al. (2000a) also used isozymic analysis to evaluate 467 accessions from the $D$. cayenensis/rotundata complex and identified 227 cultivars. Twenty-eight genotypes were identified within 45 accessions of Guinea yams (D. cayenensis/D. rotundata complex) by Mignouna et al. (2002) using 6 enzymatic systems.

Cluster analysis for the $21 \mathrm{D}$. cayenensis and $2 \mathrm{D}$. rotundata accessions showed the formation of 4 groups that were defined with the aid of the bootstrap analysis (Figure 2). The Jaccard similarity coefficient varied between 0.20 and 1.00 , showing $80 \%$ similarity variation, indicating the existence of great diversity among the D. cayenensis accessions that were collected in the households of traditional farmers in Vale do Ribeira.

Group I classified most of the accessions that originated from several communities in the municipalities of Iguape, Cananeia, Ilha Comprida, Iporanga, and Eldorado. No separation 


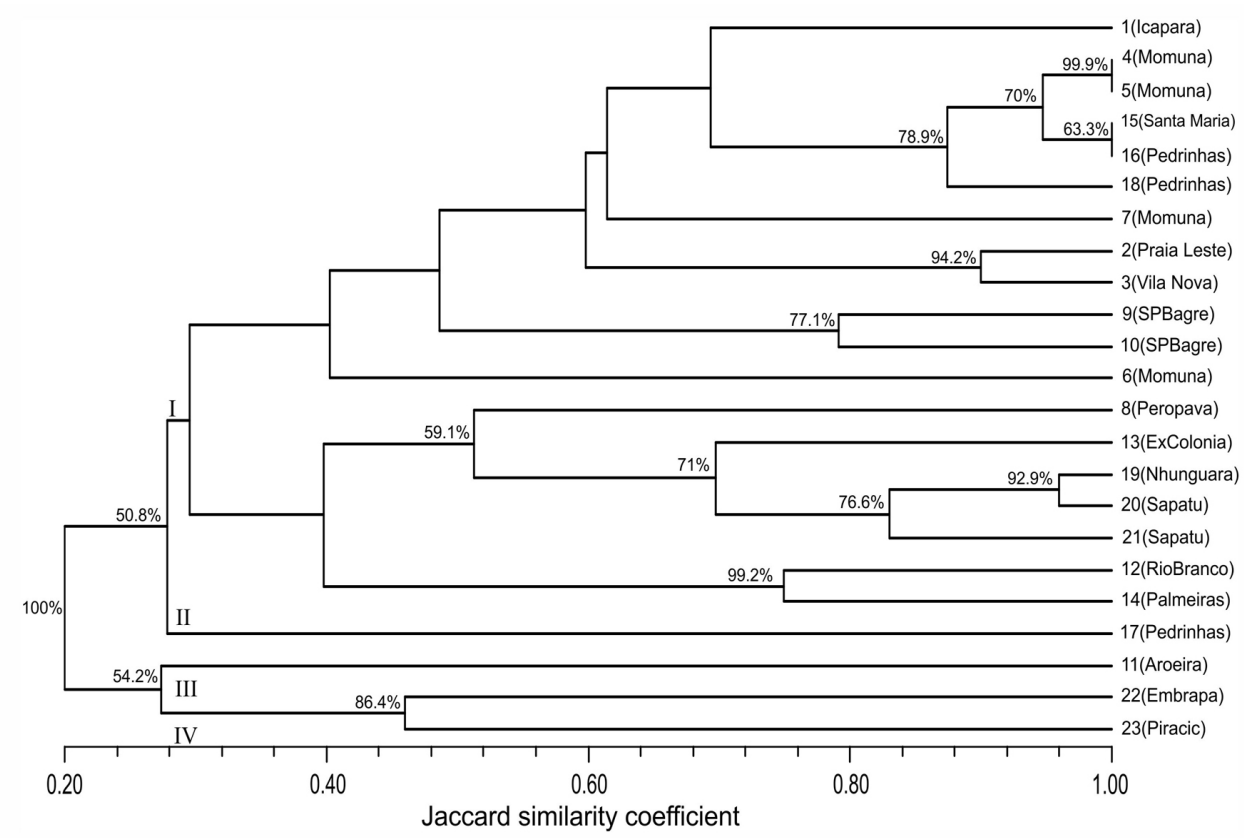

Figure 2. Cluster analysis using the UPGMA method for the 21 Dioscorea cayenensis and two D. rotundata accessions (22 and 23) based on isozymic data, according to the similarity index of Jaccard.

of landraces according to the community or municipality was observed. The landraces that originated from Momuna and Iguape were classified into different subgroups within this group, except for a duplicate among individuals 4 and 5 from household No. 4 . Therefore, in this household of Momuna, 2 accessions with the same isozyme phenotype were identified, although the farmer identified them as different materials with the same local name (cará de espinho) (Table 1). Accessions 15 (cará guaçu) and 16 (cará de espinho), which were obtained from households 13 and 14 in the communities Santa Maria, Cananéia and Pedrinhas, Ilha Comprida, respectively, showed the same isozyme phenotype. Although farmers have identified these 2 accessions with different local names, they have the same origin because, according to information provided by the farmer in Pedrinhas, he obtained this tuber from a friend in Santa Maria. The 2 pairs of duplicates mentioned above (accessions 4 and 5; accessions 15 and 16), representing landraces from Iguape, Cananéia, and Ilha Comprida, presented high genetic similarity (about $95 \%$ similarity) and therefore show no spatial structure for $D$. cayenensis local varieties in Vale do Ribeira. This fact is likely to be because of the anthropogenic exchange of materials between friends and neighbors in the region, as shown in the report of the 2 farmers from Pedrinhas and Santa Maria.

A few similarities between geographically closer varieties were also observed in group I. Local varieties 9 and 10, from São Paulo Bagre, were grown in the backyards of houses situated close to each other, and showed about $80 \%$ similarity. This community is located in the Environmental Protection Area in the municipality of Cananéia, where farmers are prohibited by law from having open fields; thus, the species is being cultivated in their home gardens. Local varieties 19, 20, and 21 originated from Nhunguara, Iporanga, and Sapatu, Eldorado. These 
3 accessions show approximately $85 \%$ similarity, which is probably due to the proximity of these communities. The local varieties 12 and 14, from Rio Branco and Palmeiras, which are both in the Cananéia municipality, showed $75 \%$ similarity. The farmers in these communities reported exchanging materials among themselves. In addition, these communities are quite close geographically.

Group II classified accession 17, from Pedrinhas, Ilha Comprida. Accessions from only 1 household (No. 14) were collected in Pedrinhas, and 2 of them showed great genetic similarity, more than $80 \%$, and were classified in group I. In contrast, accession 17 showed greater genetic differentiation from other accessions (Figure 2). Group III consisted of accession 11, which was from Aroeira, and was the only local variety that was obtained in this community.

Group IV was formed by the 2 D. rotundata accessions that showed $45 \%$ similarity. The analysis also showed the separation of these 2 accessions from the other $D$. cayenensis accessions. One of the D. rotundata accessions originated from Cruz das Almas, Bahia, but the other was acquired in Piracicaba and had the popular name cará do Norte, which means yam from the North. At the market, we were informed that this tuber plant came from the northeast region of Brazil. These tubers were morphologically different and were sold as different from the yams that were marketed in the State of São Paulo, which belong to D. alata. In a recent study of tubers that were collected in different regions of Brazil, Veasey et al. (2010) observed that accessions predominating in the South and Southeast are those with morphological characteristics that would classify them as $D$. cayenensis, while most of the accessions collected in the Northeast were shown to have the morphological traits of D. rotundata. Indeed, it was on the basis of morphological differences that these 2 accessions were identified as D. rotundata.

Based on data from 65 polymorphic bands, AMOVA showed that the variability is distributed in equilibrium among households within communities $(42.5 \%)$ and between communities (40.3\%) (Table 3), confirming the data that are presented in Figure 2. This, again, indicated the absence of genetic structure and emphasized the importance of the evolutionary units (gardens and communities) in the distribution of the genetic diversity of $D$. cayenensis. The distribution of variability is probably related to genetic recombination because the sexual system of this species remained active despite vegetative reproduction. Together with this factor, the unconscious management of the traditional farmers favors the increase of genetic diversity (Martins and Oliveira, 2009). Peroni and Martins (2000) demonstrated the relationship between farm management and components of the life history of cassava in the gardens of traditional farms in the Vale do Ribeira, as human disturbance favors microevolutionary processes and, consequently, the maintenance of genetic diversity that is kept by farmers.

\begin{tabular}{|c|c|c|c|c|c|c|}
\hline \multirow[t]{2}{*}{ Source of variation } & \multicolumn{3}{|c|}{ Isozyme markers } & \multicolumn{3}{|c|}{ Morphological markers } \\
\hline & d.f. & MS & $\%$ of total variation & d.f. & MS & $\%$ of total variation \\
\hline Between communities & 13 & 141.45 & $40.26^{*}$ & 13 & 77.74 & $36.58^{\text {ns }}$ \\
\hline Between households within communities & 3 & 17.00 & $42.54^{\text {ns }}$ & 3 & 10.00 & $44.81^{\mathrm{ns}}$ \\
\hline Within households & 4 & 5.83 & $17.20^{* *}$ & 4 & 3.50 & $18.61^{* *}$ \\
\hline Total & 20 & 164.29 & & 20 & 91.24 & \\
\hline
\end{tabular}




\section{Morphological analysis}

Of the 19 morphological traits, 9 were shown to be fixed for the species $D$. cayenensis and D. rotundata. Therefore, the 23 accessions that were evaluated presented green stems with no wings; additionally, all had spines, a round stem cross-section shape at the base, and a counterclockwise twining direction. All leaves showed 1 leaflet and a cordate shape. All of the accessions produced tubers with a brown tuber skin color.

As for the stem color, $91.3 \%$ presented green color while $8.7 \%$ ( 2 accessions) showed a purplish green color. Most of the accessions (65.3\%) showed a stem diameter between 0.4 and $0.6 \mathrm{~cm}$, while $34.8 \%$ presented diameters that were greater than $0.6 \mathrm{~cm}$. The position of the leaves was an important trait to differentiate the 2 D. rotundata accessions, which showed opposite leaves, in contrast to the $D$. cayenensis accessions, which showed alternate leaves. Only 4 accessions (17.4\%) flowered, including the 2 D. rotundata accessions and accessions 10 and 14 from São Paulo Bagre and Palmeiras, Cananéia, respectively.

As for the tuber traits, most of the accessions $(78.3 \%)$ produced several tubers (more than 5), while $21.7 \%$ produced just a few (2-5 tubers). Most of the accessions (56.5\%) produced an elongate tuber shape and totally fused (91.3\%) tubers. Only 2 tuber colors were observed, yellow $(78.3 \%)$ and white $(21.7 \%)$. This trait should also differentiate the 2 species. In fact, the 2 D. rotundata accessions showed the white color, which is characteristic of this species. However, 3 other accessions that were considered D. cayenensis showed white tuber colors as well $(12,13$, and 14 from different communities in Cananéia municipality). This is one of the reasons that it is sometimes difficult to separate the 2 species, and why they are considered to be a species complex by some authors (Mignouna et al., 2002; Scarcelli et al., 2006), although other authors were able to genetically differentiate both species (Dansi et al., 2000a).

This species complex has been studied through the techniques of isozymes and morphological analysis by Hamon and Toure (1990), who evaluated 453 accessions and obtained results that showed good agreement between the 2 techniques. Good agreement between the 2 markers was also observed by Mignouna et al. (2002), who used these techniques successfully to identify cultivars from the $D$. cayenensis/D. rotundata complex in Cameroon, West Africa.

Cluster analysis that was obtained from the morphological characterization revealed the formation of 2 groups (Figure 3). Group I consisted of all accessions from Vale do Ribeira. The local varieties from Iguape were separated within a subgroup of group I (accessions 1, 2, 3, 4, 5, 7, and 8), except accession 6 from Momuna, Iguape, which clustered with another subgroup that included accessions from Cananéia, Ilha Comprida, Iporanga, and Eldorado municipalities. However, the bootstrap analysis does not support the separation of these subgroups, which is why they must be regarded as belonging to 1 group. Group II classified the 2 D. rotundata accessions, with both originated from the Northeast. As mentioned above, one of the main traits responsible for the separation of the 2 species was the position of leaves on the stem, which was opposed for these 2 accessions. Both accessions also had the white flesh color, and both showed flowering under the climatic conditions of Piracicaba, São Paulo.

The 3 accessions from Pedrinhas, Ilha Comprida (16, 17, and 18), both accessions from Sapatu, Eldorado (20 and 21), and the accession from Nhunguara, Iporanga (19) were duplicates, and these 6 accessions had a Jaccard similarity coefficient of 1 (Figure 3). These individuals presented, therefore, the same morphological phenotype despite being collected in different communities of Vale do Ribeira (Table 1, Figure 1). Nhunguara and Sapatu are geo- 


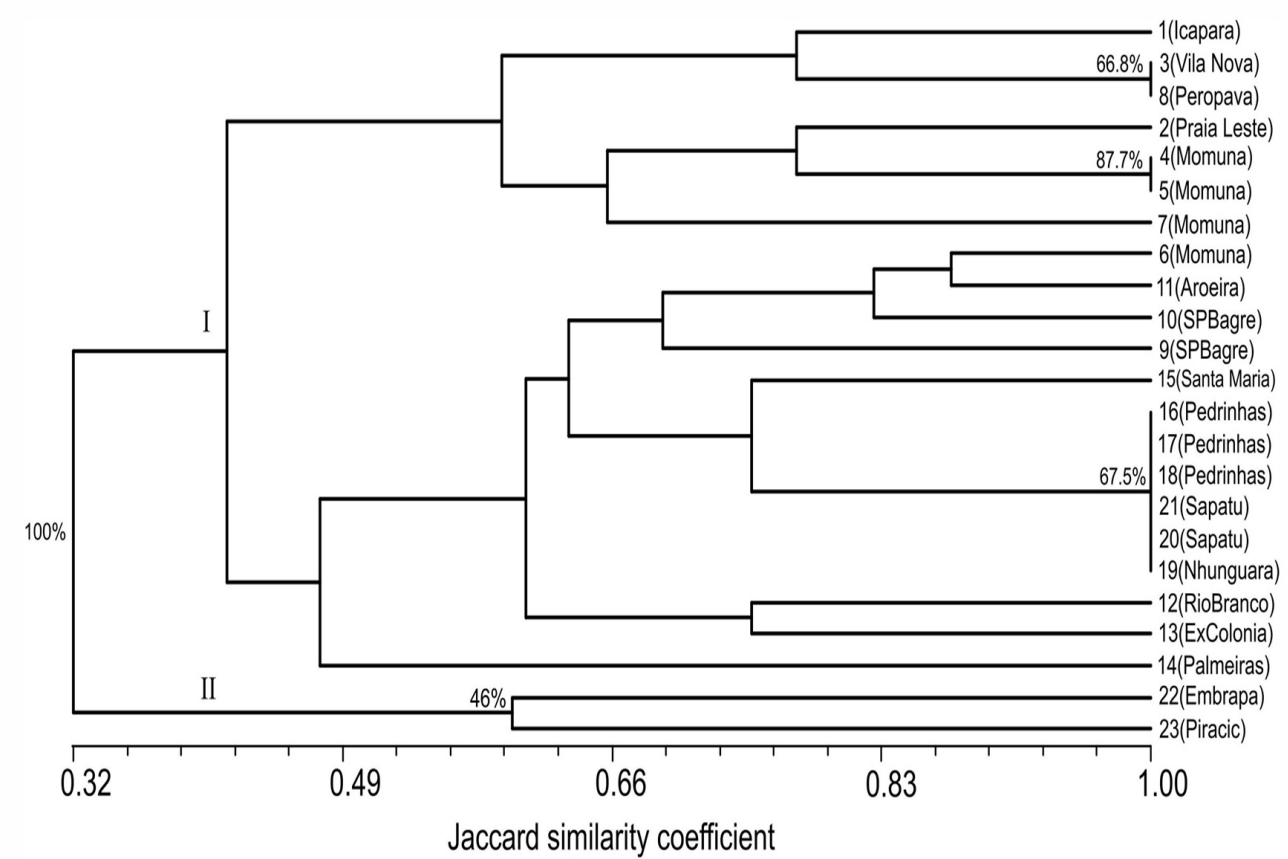

Figure 3. Cluster analysis using the UPGMA method for 21 Dioscorea cayenensis and two D. rotundata accessions (22 and 23) based on 19 morphological characters, according to the similarity index of Jaccard.

graphically closer, both from Quilombola communities in the municipalities of Iporanga and Eldorado Paulista, which may have rendered a favorable exchange of materials between these communities. Interestingly, the 2 accessions from Sapatu and the accession from Nhunguara proved to be genetically very similar in the isozyme analysis, which agreed with the result of the morphological analysis. Another duplicate pair that was observed in the morphological analysis, accessions 4 and 5 from Momuna, was also observed in the isozyme analysis, indicating that these 2 accessions represent 2 genetically identical clones. Another duplicate was found in the morphological analysis of accessions 3 from Vila Nova and 8 from Peropava; both of these are located in Iguape. However, they were shown to be distant from each other, although they were in the same group, in the isozyme analysis.

Although all accessions from Vale do Ribeira were classified in a single group in the cluster analysis (Figure 3), the local varieties that were cultivated by traditional farmers presented a similarity range of more than $50 \%$ for the morphological traits. This result demonstrates the existence of high diversity for morphological characteristics among the cultural units.

The local names given by traditional farmers in Vale do Ribeira for D. cayenensis (cará de espinho, cará d'Angola, and cará guaçu) hid the genetic diversity within communities and municipalities. Most farmers called this species cará de espinho, although results have shown genetic differences among these so-called varieties. Cará guaçu and cara d'Angola were given by 2 and 1 farmers, respectively, in the municipality of Cananéia, where the name cará guaçu was also assigned to another yam species $(D$. alata $)$. In the northeast region of Brazil, this species, whose accessions were mostly identified as D. rotundata, is known mainly as 
inhame da Costa, but other local names are also found in this region, including inhame de Pernambuco, inhame original, inhame Japecanga, and inhame cará babão (Veasey et al., 2010).

AMOVA showed that $44.8 \%$ of the variability was found among households within communities (Table 3 ) and $36.6 \%$ of the variability was among communities. Thus, diversity may be generated by sexual reproduction or other evolutionary factors, in addition to human selection of morphological characteristics of interest, which includes the cultural habits of the community as a parameter of selection. Martins and Oliveira (2009) reported that the farmer does not select seeds for dormancy loss, as in the case of domesticated grasses and legumes, because yam propagation is made through the tubers, which enables the formation of seed banks in the soil.

Flowering was an important descriptor for $D$. cayenensis. As stated above, only $17 \%$ of the accessions produced flowers under the biotic and abiotic conditions of Piracicaba, where the experimental field was located. This is an important observation that indicates the possibility of generating genetic variability through interbreeding in this species. Although the farmer ignored the sexual reproduction of the cará de espinho and propagated it vegetatively, the sexual system of this species remained active, which was evident because some farmers reported the presence of flowers and fruits in this species. Another point that draws attention is the maintenance of this species in abandoned fields (fallow). During a survey in a caiçara community, Pedrinhas in Ilha Comprida, and a quilombola community, Ivaporunduva, yam (Dioscorea $\mathrm{spp}$ ) seeds were found in the topsoil $(10 \mathrm{~cm}$ deep), thus reinforcing the possibility of genetic diversity amplification through sexual reproduction (Martins and Oliveira, 2009).

\section{Correlation between isozymes, morphological markers, and geographical distances}

The correlation between genetic and geographical distances was zero $(r=-0.13)$ and not statistically significant for the isozyme data. The probable reason for this is the random exchange of materials between cultural units, as already mentioned above, according to farmer accounts. The addition of genetic variability through sexual reproduction is another hypothesis. Also, no correlation was observed between genetic and geographical distances $(r=-0.05)$ for the morphological data, suggesting that the distribution of local varieties is linked to anthropogenic factors such as the cultural habits of each community and the generation of diversity through the sexual reproductive system.

The correlation coefficient that was obtained between isozymes and morphological markers was zero $(r=-0.05)$ and not statistically significant $(P=0.99)$, suggesting that these 2 parameters were not correlated. This result was expected because different regions of the genome were sampled for both types of markers. The individuals that showed identical isozyme patterns (15 and 16) (Figure 2) had a different morphology (Figure 3), but the differences were small in magnitude. However, accessions 4 and 5 were shown to be duplicates for both isozymes and morphological traits.

Farmers are faced with morphological variations that do not reflect the isozymic differences. Sexual reproduction and microevolutionary processes together combine with the skills of the farmer to select the "observed" variation that is clearly discriminated by the morphology of the plants, and the farmer ignores the "hidden" variability (genes). Quiros et al. (1990) demonstrated in their study with potatoes in the Peruvian Andes the underestimation of genetic variability in autochthonous agriculture. 
The information that was obtained from the estimation of genetic diversity with both isozymes and morphological characterization revealed that traditional farmers maintain and manage high variability in their communities. Therefore, both markers were suitable for the study of diversity in $D$. cayenensis. However, there is no agreement between the system of "folk" taxonomy and the genetic markers because the farmers' notion of "variety" hides high levels of diversity within the same community or municipality. Both markers demonstrated the separation of the 2 species, $D$ cayenensis and $D$. rotundata. With respect to $D$. cayenensis, most of the diversity, although not structured in space, is found among households in traditional communities of Vale do Ribeira.

\section{ACKNOWLEDGMENTS}

The authors wish to thank Fundação de Amparo à Pesquisa no Estado de São Paulo (FAPESP) and Conselho Nacional de Desenvolvimento Científico e Tecnológico (CNPq) for providing scholarships and financial support for this research. We wish to thank Dr. Nivaldo Peroni, Universidade Federal de Santa Catarina, and the technician Domingos de Sávio Amaral for collaborating with this research and the agriculturists from Vale do Ribeira for contributing plant material.

\section{REFERENCES}

Alfenas AC, Peters I, Brune W and Passador GC (1991). Electrophoresis of Proteins and Isoenzymes of Fungus and Forest Plants. UFV, Viçosa.

Asemota HN, Ramser J, Lopéz-Peralta C, Weising K, et al. (1996). Genetic variation and cultivar identification of Jamaican yam germplasm by random amplified polymorphic DNA analysis. Euphytica 92: 341-351.

Bressan EA, Veasey EA, Peroni N, Felipim AP, et al. (2005). Collecting yam (Dioscorea spp.) and sweet potato (Ipomoea batatas) germplasm in traditional agriculture small-holdings in the Vale do Ribeira, São Paulo, Brazil. Plant Genet. Resour. Newsl. 144: 8-13.

Bressan EA, Briner Neto T, Zucchi MI, Rabello RJ, et al. (2011). Morphological variation and isozyme diversity in Dioscorea alata L. landraces from Vale do Ribeira, Brazil. Sci. Agric. 68: 494-502.

Coelho ASG (2001). BOOD: Dendrogram Evaluation Based on Estimates of Genetic Distances/Similarities Through the Bootstrap Procedure (Software). Universidade Federal de Goiás, Instituto de Ciências Biológicas, Goiânia.

Dansi A, Mignouna HD, Zoundjihekpon J, Sangare A, et al. (1999). Morphological diversity, cultivar groups and possible descent in the cultivated yams (Dioscorea cayenensis/D. rotundata) complex in Benin Republic. Genet. Resour. Crop Evol. 46: 371-388.

Dansi A, Mignouna HD, Zoundjihékpon J, Sangare A, et al. (2000a). Using isozyme polymorphism to assess genetic variation within cultivated yams (Dioscorea cayenensis/Dioscorea rotundata complex) of the Republic of Benin. Genet. Resour. Crop Evol. 47: 371-383.

Dansi A, Mignouna HD, Zoundjihékpon J, Sangare A, et al. (2000b). Identification of some Benin Republic's Guinea yam (Dioscorea cayenensis/Dioscorea rotundata complex) cultivars using randomly amplified polymorphic DNA. Genet. Resour. Crop Evol. 47: 619-625.

Excoffier L, Smouse PE and Quattro JM (1992). Analysis of molecular variance inferred from metric distances among DNA haplotypes: application to human mitochondrial DNA restriction data. Genetics 131: 479-491.

Excoffier L, Laval G and Schneider S (2006). Arlequin Ver. 3.11: An Integrated Software for Population Genetics Data Analysis (Software). Institute of Ecology and Evolution, University of Bern, Bern.

FAO (2011). FAOSTAT 2011 Data Base. Available at [faostat.fao.org]. Accessed 2012.

Ferreira Junior O (2004). TrackMaker. Available at [www.gpstm.com/port]. Accessed 2011.

Hamon JR and Toure B (1990). Characterization of traditional yam varieties belonging to the Dioscorea cayensisrotundata complex by their isozymic patterns. Euphytica 46: 101-107.

IITA (2009). Yam. International Institute of Tropical Agriculture, Ibadan, Nigeria. Available at [www.iita.org/yam]. Accessed 2012. 
IPGRI/IITA (1997). Descriptors for Yam (Dioscorea spp.). International Institute of Tropical Agriculture, Rome, Italy, International Plant Genetic Resources Institute, Ibadan, Nigeria.

Lebot V (2009). Tropical Root and Tuber Crops: Cassava, Sweet Potato, Yams and Aroids. Crop Production Science in Horticulture Series: 17. CABI, Wallingford.

Mantel N (1967). The detection of disease clustering and a generalized regression approach. Cancer Res. 27: 202-209.

Martin FW and Rhodes AM (1978). The relationship of Dioscorea cayenensis and D. rotundata. Trop. Agr. 55: 193-206.

Martins OS and Oliveira GCX (2009). Dinâmica Evolutiva em Roças de Caboclos Amazônicos. In: Diversidade Biológica e Cultural da Amazônia (Vieira ICG, Silva JMC, Oren DC and D'incao MA, eds.). 2a . ed. Museu Paraense Emílio Goeldi, Belém, 373-391.

Mignouna HD, Dansi A and Zok S (2002). Morphological and isozymic diversity of the cultivated yams (Dioscorea cayenensis/Dioscorea rotundata complex) of Cameroon. Genet. Resour. Crop Evol. 49: 21-29.

Mignouna HD, Abang MM and Fagbemi SA (2003). A comparative assessment of molecular marker assays (AFLP, RAPD and SSR) for white yam (Dioscorea rotundata) germplasm characterization. Ann. Appl. Biol. 142: 269-276.

Mignouna HD, Abang MM, Wanyera NW, Chikaleke VA, et al. (2005). PCR marker-based analysis of wild and cultivated yams (Dioscorea spp.) in Nigeria: genetic relationships and implications for ex situ conservation. Genet. Resour. Crop Evol. 52: 755-763.

Obidiegwu JE, Kolesnikova-Allen M, Ene-Obong E, Muoneke C, et al. (2009a). SSR markers reveal diversity in Guinea yam (Dioscorea cayenensis/D. rotundata) core set. Afr. J. Biotechnol. 8: 2730-2739.

Obidiegwu JE, Loureiro J, Ene-Obong E, Rodrigues E, et al. (2009b). Ploidy level studies on the Dioscorea cayenensis/ Dioscorea rotundata complex core set. Euphytica 169: 319-326.

Peroni N and Martins PS (2000). Influência da dinâmica agrícola itinerante na geração de diversidade de etnovariedades cultivadas vegetativamente. Interciência $25: 22-29$.

Quiros CF, Brush SB, Douches DS, Zimmerer KS, et al. (1990). Biochemical and folk assessment of variability of Andean cultivated potatoes. Econ. Bot. 44: 254-266.

Rohlf J (1992). NTSYS-pc: Numerical Taxonomy and Multivariate Analysis System, Version 1.70 (Software). Stony Brook, New York.

Scarcelli N, Dainou O, Agbangla C, Tostain S, et al. (2005). Segregation patterns of isozyme loci and microsatellite markers show the diploidy of African yam Dioscorea rotundata $(2 \mathrm{n}=40)$. Theor. Appl. Genet. 111: 226-232.

Scarcelli N, Tostain S, Mariac C, Agbangla C, et al. (2006). Genetic nature of yams (Dioscorea sp.) domesticated by farmers in Benin (West Africa). Genet. Resour. Crop Evol. 53: 121-130.

Veasey EA, Siqueira MVBM, Gomes LR, Nascimento WF, et al (2010). Ocorrência e Diversidade de Espécies Cultivadas do Gênero Dioscorea em Diversos Agroecossistemas Brasileiros. Vol. 1. In: Agrobiodiversidade no Brasil (Ming LC, Amorozo MC and Kffuri CW, eds.). NUPEEA, Recife, 45-74.

Zoundjihekpon J, Hamon S, Tio-Touré B and Hamon P (1994). First controlled progenies checked by isozymic markers in cultivated yams Dioscorea cayenensis-rotundata. Theor. Appl. Genet. 88: 1011-1016. 